\title{
Introduction: the rule of law as the common sense of global politics
}

The rule of law is humanity's greatest creation, the essential precondition of a civilised, just society. (Schuck 2000, p. 454)

It is difficult to find anyone, whether in government, foundations, corporations or universities, who does not favour encouraging the rule of law in virtually every country and society. (Upham 2004, p. 280)

In an age of images and symbols, elections are easy to capture on film. But how do you televise the rule of law? (Zakaria 2003, p. 156)

The rule of law is often presented as preferable to the rule of men or the rule of force, and as I will argue throughout this book, this has become the common sense of global politics, an unquestioned statement about the world in which we live. To make my starting point clear, it seems to me that common sense includes three elements: norms (preferred practices); ideas (arguments and reasons to support such norms); and rhetoric (discussion of the settled character of such practices). ${ }^{1}$ Thus, a common sense notion is a set of practices or actions that are regarded as if not natural, then certainly not requiring extensive or detailed justification. When we push we might encounter statements about why these actions are sensible and require little justification, but common sense is mostly seen as unobjectionable and seldom subject to any extensive critical discussion. The discussion and rhetoric of any common sense takes its practices (and their associated reasons) for granted, often failing to specify them in anything other than a bland and/or allusive manner. I will expand on the role of common sense when I explore 'social imaginaries' in the next chapter, and as I develop the argument throughout the book I hope that what I mean when I say the rule of law is a common sense of global politics will become clear; it is an idea whose alternates seem unwelcome or nonsensical without requiring any detailed discussion of the reason(s) for this preference.

${ }^{1}$ I thank Andrew Baker for helping to clarify my idea of common sense and an anonymous publisher's reviewer of the manuscript for suggesting this should be clearly established at the start. 
As you would expect, later in this book I will explore in some detail how we might define and understand the rule of law, but here and before going further, it will be useful to at least offer a brief sketch. Adriaan Bedner's recent survey of debates about what constitutes the rule of law helpfully offers a concise scoping of the issue. He suggests that the rule of law is generally seen as serving two clear functions: 'to curb arbitrary and inequitable use of state power' and 'to protect citizens' property and lives from infringements or assaults by fellow citizens' (Bedner 2010, pp. 50, 51). Bedner acknowledges continuing debates about the rule of law, but sorts the elements that are commonly appealed to into three general categories. First, there are 'procedural' elements:

- rule by law; state actions are subject to the law

- law is formalized (clear, certain/fixed; accessible and predictable in application)

- democracy (consent can determine or at least influence legal actions) (Bedner 2010, pp. 56-63).

These procedural elements are complemented by a number of 'substantive' elements:

- law is subordinate to justice

- individual rights and liberties are to be protected

- human rights are respected, as are group rights (Bedner 2010, pp. 63-7).

Finally, he also includes two 'controlling' mechanisms or guardian institutions:

- an independent judiciary

- administrative and other independent bodies are responsible for reviewing legal process (Bedner 2010, pp. 67-9).

Much of this will become increasingly familiar as you read on.

Consequently, debates about the rule of law usually revolve around the relative importance of various of these elements with some commentators arguing that only the procedural aspects are required to assert that the rule of law obtains (a 'thin' view of the rule of law), while others (arguing for the law as a moral value) maintain that without the more substantive aspects no society can be said to enjoy the rule of law (often termed a 'thick' view). There are also debates about which aspects of the law might belong in which category! Some authors, such as Nigel Simmonds (2007), 
reject these oppositions, insisting that the law is always a moral (or thick) concept because it is never merely descriptive but rather is always an aspiration about the ordering and governing of society (in its distinction from the rule of force or personal fiat). These debates led Jeremy Waldron to suggest that the rule of law is actually an essentially contested concept (Waldron 2002), and consequently, we must understand it not as an absolute that is either present or absent but rather the sort of norm that will vary in degree across all its elements (Waldron 2008, p. 44), requiring nuanced and qualified assessments of some complexity.

There is much more to be said about how we might understand the rule of law and the elements that make up the threshold conditions for an acceptable claim to be made that the rule of law exists in any specific society or community. However, before starting to unpack the rule of law, in this Introduction I will look at the various political discourses that celebrate the rule of law (including a specific discussion of the World Bank's position), as well as the more public discussions in the news media (exemplified by, but not limited to, The Economist). The rhetoric of the rule of law encourages a widespread (although unevenly developed) consciousness of its claimed value, and most importantly influences 'modes of thought' by being integrated into individuals' world-view, normalizing the law so that even in extra-legal activity the law is always there as a potential alternative for the resolution of conflict (Berman 2005, pp. 493-5). I have chosen the examples below to illustrate the recitation of the rule of law as a common sense, but they are also intended to begin to show how rhetoric plays a role in (re)producing the dynamic that I examine in subsequent chapters. Unfortunately, conclusively demonstrating the domination of a political discourse that privileges law would require a much more detailed study than this book has space for. Rather, here I will explore some of the contours of the rhetoric of the rule of law, trusting that this will find an echo in your own experience of discussions of (global) politics in the media, and expert and academic commentary as well as elsewhere when global politics is talked about.

It is often observed in the specialist literature that the idea of, and the term, the rule of law has progressively become more widely used in recent decades. As Pietro Costa and Danilo Zolo point out, today the "expression the "rule of law" is remarkably widespread, not only in political and legal literature but, most notably, in newspapers and political language' (Costa and Zolo 2007, p. ix). Likewise, at the turn of the millennium Adam Bouloukos and Brett Dakin observed: 'In recent years, no discussion of international development or debate over foreign policy has been complete without some mention of the "rule of law" (Bouloukos and Dakin 2001, p. 145). More recently, Stephen Holmes argued that the rhetoric of 
the rule of law has been 'successful in globalising that set of ideas, and associating them with certain constructions of the legal, the social and the economic'; it is a 'term of art that saturates contemporary political life and accommodates increasingly broad political desires' (Holmes 2010, pp. 220, 224). Indeed, it is a term freighted with emotion, as Frederick Schauer has observed: 'Insofar as legal systems are perceived to have achieved some measure of success, "the rule of law" becomes synonymous with "the good things about the legal system"' (Schauer 1989, p. 70). However, Waldron notes, it sometimes seems as if it has no more meaning than a manner of cheering 'Hooray for our side' (Waldron 2002, p. 139); it may be little more than a rhetorical flourish. Thus, certainly in debates about governance and government, the rhetoric of the rule of law is common, and may well have been one of the earliest enlightenment values of modernity to be espoused (Sampford 2006, p. 275), but it remains remarkably indeterminate, being frequently evoked on both sides of an argument.

This lack of fixed meaning may actually make the term attractive. As Balakrishnan Rajagopal suggests in his discussion of post-conflict rule of law support programmes, the rule of law is often preferred to a discourse of human rights precisely because it is largely "empty of content and capable of being interpreted in many diverse, sometimes contradictory ways' (Rajagopal 2008, p. 1359). It may be that the term itself can be regarded as less emotional to invoke than 'human rights' and therefore may serve the interests of those wishing to take a quieter road towards democratization (and liberalization) (Bouloukos and Dakin 2001, p. 158). Thus, generally the rule of law seems to carry with it less problematic intellectual baggage than other developmental terminology and can be presented as non-political in difficult (post-conflict) situations where political order is fragile (or failing).

\section{THE POPULAR RHETORIC OF THE RULE OF LAW}

If the rule of law is now common sense we would expect to find it popping up frequently and widely in discussions of all sorts of global politics. Indeed, Andrew Cortell and James Davis have observed that the 'first sign of an international norm's domestic impact is its appearance in the domestic political discourse' and as it becomes more salient it will be the violation of its strictures that will need to be justified not its observance or adoption (Cortell and Davis 2000, pp. 70-1). This is clearly evident, for example, in the political arguments around the (non-)prosecution of British Aerospace relating to bribery in the al-Yammamah/Saudi Arabia arms contract made by the then UK Attorney General (Lord Goldsmith); 
while acknowledging the 'need to maintain the rule of law', he asserted that it was subordinate to realpolitik concerns around 'security, intelligence and diplomatic cooperation' with the Saudis. ${ }^{2}$ In response to the continued non-prosecution, Eric Metcalfe of Justice noted that it was 'a sad day for the rule of law when a senior prosecutor bows to threat from a foreign government and our most senior judges will do nothing to stop it'. ${ }^{3}$ Indeed, much of the political discussion of this case as it worked its way through the UK courts for two years involved its impact on the UK's reputation for abiding by the rule of law, not least of all as non-prosecution broke commitments made when the UK signed the Organisation for Economic Co-operation and Development's (OECD) anti-bribery convention.

Leaving the impact the rule of law has on political practice for later, here I am concerned with the articulation of the rule of law in these domestic (popular) discussions and debates. In this I agree with Andrew Loomis's suggestion that it is

reasonable to assume that the mass public is less cognizant than elites of highly sophisticated cause-effect relationships, but more likely to privilege policies perceived to be based on principles that coincide with widely accepted societal values derived from the national experience. (Loomis 2012, p. 83)

While popular politics may have little engagement with the jurisprudential debates I discuss later, the more general notion of the importance of the rule of law has much more salience and political purchase (not least as it is amenable to quite radical simplification). Moreover, this may relate to popular conceptions of what constitutes a country's political character (Loomis 2012, p. 87). Recently Roger Scruton, in discussing the values of British society, argued that the 'rule of law requires a shared allegiance, by which people entrust their collective destiny to sovereign institutions that can speak and decide in their name', emphasising the manner in which British law was able to articulate our values by virtue of the development of common law as the rule of law (Scruton 2013). And interestingly, Lord Goldsmith, prior to his decision in the al-Yammamah case, himself observed that the rule of law "crops up in the [British] press as being something that defines our society ... [a]nd regimes which engage in abhorrent practices such as torture are condemned for their failure to respect the rule of law' (Goldsmith 2006, p. 4). These invocations of the rule of law often seem to have a multi-layered meaning; something quite clear and

\footnotetext{
2 'The BAE affair sends all the wrong signals', Observer, 17 December 2006, p. 24.

${ }^{3}$ Quoted in 'Timid justice: BAE and the Saudi arms deal', The Economist, 2 August 2008, p. 37.
} 
simple for popular appeal, alongside a more legalistic understanding for specialists. Thus, Goldsmith maintains a simple definition for his audience - government to be constrained by law; it is not merely rule by law but has some normative content; and universal application - while also pointing to a more complex literature that he is bypassing for ease of argumentation (Goldsmith 2006, pp. 4-8). This is one important key to the rule of law's growing appeal as a global political common sense; its flexibility in use.

The notion of the rule of law certainly has significant popular currency. In the trailer for the film of the stage play Frost/Nixon, a quote from the original interview of 19 May 1977 was used, and spoken by the actor playing President Nixon: 'When the President does it, that means that it is not illegal.' Clearly intended to be a shock by virtue of David Frost's in-film response, and where it was placed in the trailer, this suggests how widely the norm of the rule of law (as opposed to the rule of the individual) may be accepted, even by those who would probably find it difficult to describe its more formal dimensions. In a different sort of example, in 2009 Andrew Young (a US clergyman with strong civil rights interests) was quoted as saying, 'Nothing is illegal if one hundred well-placed businessmen decide to do it. ${ }^{4} \mathrm{~A}$ remark that was clearly presented as ironic by the Financial Times, again, testifying to the common acceptance of the norm of the rule of law. More explicitly, a distinguished UK senior judge, (the late) Lord Bingham, noted that the rule of law is 'constantly on people's lips' (Bingham 2010, p. vii), although he worried that is not well understood, even as it is deployed in political discussion and debate..$^{5}$ Three year's previously, Scott Horton, writing in the US magazine Harpers, had set out a critique of the Bush Administration's policy towards Guantanamo detainees as a 'war on the rule of law', which he defined utilizing a discussion of British legal history (Horton 2007).

As these four examples begin to suggest, within our (globalized) political discourse the importance of abiding by the rule of law has significant appeal, with the norm widely discussed in a range of places. In another example, in Joseph Stiglitz's recent intervention into debates about inequality, he spends some pages focusing on the rule of law primarily as regards access to justice, although he appears to see no need to define or explore the term more generally (Stiglitz 2013, pp. 234-58). A more detailed account runs through much of Niall Ferguson's revisionist celebration of the British Empire (a book and TV series). Here, the British concern with law and the introduction of common law procedures and practices is presented as having had a significant developmental

\footnotetext{
4 Andrew Young, 'Wit and wisdom', FT Magazine, 6 June 2009, p. 13.

5 See my discussion of the book in May (2011).
} 
pay-off for post-colonial states lucky enough to have been part of the Empire; indeed he concludes that "we should not underestimate the benefits conferred by British law and administration' (Ferguson 2003, p. 361). Moreover, he argues that due to the increasing liberal character of imperial policy the 'rule of law had to take precedence, regardless of skin colour' (Ferguson 2003, p. 195), and as such the imposition of this norm led to the establishment of legal systems that would subsequently be advantageous to societies in the post-imperial period. This presentation of the rule of law's centrality was expanded eight years later in his account of Civilisation where (in a triumph of anachronism) the rule of law is presented as one of the 'killer aps' for the achievement of a modern civilized society (Ferguson 2011). Likewise, in Samuel Huntington's widely cited and discussed Clash of Civilisations the rule of law is listed as one of the key distinguishing characteristics of Western society (Huntington 2002 , p. 70), a significant change from the position he had adopted earlier (discussed in the next section). These books have been widely discussed in the media, with their authors approached for comment pieces and TV or radio appearances, and as such the rule of law as popular rhetoric has been reinforced through use.

In another widely discussed recent volume, Why Nations Fail, Daron Acemoglu and James Robinson similarly suggest that the rule of law is a key component in the political virtuous circle they see supporting economic development. Focusing on political institutions and the incidence of inequality, the authors regard the rule of law as an integral part of the progressive establishment of a pluralist polity that can support the innovation and enterprise that supported (and supports) successful economic development (Acemoglu and Robinson 2012, pp. 302-34, passim). They see the rule of law as a norm that by virtue of its own logic may serve the needs of the wealthy, but thereby also protects and supports the rights of the general populace. ${ }^{6}$ However, the norm is underspecified in this account, with its contours sketched in around only one (albeit important) element; equality in law. The authors indicate that the rule of law is more than just procedure, and identify equality of treatment as the manner in which it differs from the rule by law (where laws can be applied to different groups differently), but their treatment of the rule of law overall remains underdeveloped.

That there are now popular academic books that stress the rule of law as a key component in economic development is indicative of the manner in which in the past 20 years the discussion of the rule of law has migrated from the limited and narrow legal specialist publications, where for years

${ }^{6}$ A parallel to E.P. Thompson, to whom I return later. 
the ins and outs of its definition had been explored, to a situation where the rule of law is a commonly deployed political term, increasingly requiring little explanation when used. This reached its apogee (perhaps) in the UK Constitutional Reform Act 2005 that explained (in full) in its first Article that: 'This Act does not adversely affect, (a) the existing constitutional principle of the rule of law'. ${ }^{7}$ This left the work of defining it to others, with no indication of whether further detail was absent because it was not required, as everyone would know what was meant, or that in the drafting an insoluble dispute about meaning had arisen. It certainly worried Lord Bingham, who's last book (Bingham 2010) was intended to set out an acceptable basis for understanding the term. This lack of a firm definition was also noted in the press, with Martin Kettle of the Guardian asking: 'What does the rule of law actually mean? If we cannot say what the phrase means then it is not much use as a governing principle' (Kettle 2006) before setting out Bingham's conclusions. Bingham's book was (later) published by Allen Lane, a mass market publisher, and garnered significant attention across the media.

Nor should we forget that law and its practices have become a key element in popular culture: US TV series such as Perry Mason, Boston Legal, Law \& Order, The Good Wife, Ally McBeal and LA Law as well as UK series like Rumpole of the Bailey, North Square, Silk, Judge John Deed and Kavanagh $Q C$ have all aired on primetime TV and have no doubt contributed to the familiarity many have with legal terminology and even legal debates. Indeed, in her presidential address to the Law and Society Association in Glasgow in 1996, Susan Silbey suggested that through such programmes the "practices and ideals of the law, the history and the fictions, become part of the engagement between social movements and corporate capital in diverse corners of the globe' (Silbey 1997, p. 221). If one might doubt the legal impact of TV programmes, Phillipe Sands has identified the role that the Fox TV series 24 played in contributing to the belief that torture was both effective and (legally) acceptable at Guantanamo Bay prison camp. As he makes clear in a number of places in Torture Team both military personnel and government legal advisers were enthusiastic watchers of 24 and explicitly referred to it in their discussions with Sands about procedures of interrogation at Guantanamo. This is not to claim a direct causal link but, as Sands suggests, it (de)sensitized various

${ }^{7}$ Available at http://www.legislation.gov.uk/ukpga/2005/4/contents (accessed 13 May 2013).

${ }^{8}$ For the top 25 legal TV series as voted for by the American Bar Association see http://www.abajournal.com/magazine/article/the_25_greatest_legal_tv_shows/ (accessed 4 February 2013). 
individuals to the illegitimacy of torture (Sands 2008, pp. 73-4, 87-9, 272), indicating some influence over their views of the (rule of) law.

The result of all this talk of the rule of law has led anthropologists John and Jean Comaroff to observe that it is not unusual any more to hear the Euro-language of jurisprudence in the Amazon or Aboriginal Australia. Or among the poor of Mumbai, Madagascar, Cape Town and Trench Town' (Comaroff and Comaroff 2009, p. 34). In their overview of anthropological studies of governance they find numerous and widely spread examples of the shift of politics into the law, and the use of the idea(s) of the rule of law as a language through which the poor now often articulate their political demands. For instance, in upheavals around the judiciary in Pakistan, Abdullah Freed Khan has noted that across the country in interviews with farmers, workers and others mobilizing behind the popular lawyers' movement, the idea of the value of the rule of law had considerable popular currency (Khan 2010). This is also reflected in the reception of the work of Hernando de Soto and the Commission for the Legal Empowerment of the Poor, discussed in Chapter 5; de Soto's work has been much debated and again has expanded the recognition of the idea of the rule of law in the analysis of development and economic inequality. And, as I mentioned in the Preface, much of the discussion of how to protect traditional knowledge now encompasses legal solutions despite many indigenous communities' lack of legal structures and practices that could be compatible with (what we would now call) the rule of law.

It seems likely that the discourse of the rule of law has become so common partly due to its expanding use in the press. Writing in the Wall Street Journal at the turn of the millennium, the columnist Paul Johnson suggested that the 'most important political development of the second millennium was the firm establishment, first in one or two countries, then in many, of the rule of law' (Johnson 1999). Focusing in the first instance on equality before the law and everyone being subject to it, Johnson offers a potted history of the rule of law that dates its first 'emergence' around the eleventh and twelfth centuries before plotting a course that, while recognizing crucial British developments, accords greatest value to the constitutional innovations of the American revolution. For some, this tradition has been forgotten. Discussing the Parliamentary Debate about the fate of Abu Qatada, Peter Oborne lamented, under the title 'The rule of law in Britain is diminished by the furore over efforts to deport Abu Qatada to Jordan', that the MPs seemed to have forgotten the UK's long legal history and sought to extra-legally deport a man who has committed no crime in the UK (however unpleasant one might regard him to be). $\mathrm{He}$ complained that: 
It has been very clear for a long time that something has gone wrong with British justice. A succession of Home Secretaries have targeted, at different times, each of the central principles that underlie the national system of law: trial by jury, habeas corpus, free speech, as well as the abiding tenet that there should be a strict separation of powers between the judiciary and the executive. (Oborne 2012)

The latter (partial) list will appear again as the book proceeds, as these are well-rehearsed elements of the norm of the rule of law.

Elsewhere, in light of the continuing revelations of illegal practices at international banks, before and during the financial crisis that broke in 2008, some have called for the return of the rule of law to the financial sector. For instance, Democratic Senator Ted Kaufman argued in the New York Times in 2010 that there was a need to 'return the rule of law to Wall Street, which has been seriously eroded by the deregulatory mindset that captured our regulatory agencies over the past 30 years' (Kaufman 2010). However, the appeal to the rule of law is not limited to the (global) political economy; its normative remit spreads much further. In summer 2011, after a controversy regarding the conduct of an English cricketer, James Lawton of the Independent entitled his discussion of the day's troubles: 'Rule of law is trampled on to protect "spirit of the game" (Lawton 2011). The discussion didn't invoke the norm in any detail, but clearly assumed that the rule of law itself (including the 'laws' of cricket) is an important value to be upheld. More normally the appeal to the rule of law is focused on the political realm, whether (in the UK) it was controversy over Archbishop Williams's comments on Sharia law (leading to critics invoking the rule of law against such legal pluralism) or complaints about the UK government's suspected complicity in the illegal rendition of terrorist suspects for interrogation. From discussions of the reach of News International's control of the press to the role of Twitter in libel cases, from the death of UK nationals in foreign countries (such as the investigation of the murder of Neil Heywood in China in 2012) to discussions of corporate power, it is seldom long before someone refers to the rule of law as the standard against which behaviour and practices should be judged.

Unfortunately, a full and extensive survey of this media coverage would be unwieldy to conduct here and so I will focus on one exemplary publication; here I look at The Economist as an illustration of the widely read news media discourse around the rule of law. 


\title{
THE ECONOMIST AND THE RHETORIC OF THE RULE OF LAW
}

It seems likely that the news media helps to shape and influence discourses through repeated use of particular terms and tropes over a longish period. This influence is not a single cause of shifts in political ideas, but in important ways can affect the 'mood music' of political debates. The Economist is one of the few magazines that can make a reasonable claim to be a global publication; it is not part of the "popular press' but has consistently positioned itself as the journal of record for the global business elite (Starr 2004, p. 377, 2008). Martha Starr concludes her detailed analysis of the magazine's coverage of globalization by arguing that its analysis

\begin{abstract}
alleviates anxieties about uncertainty and change by tracing out a familiar trajectory along which readers can orient themselves ... The Economist's coverage not only fulfils readers' expectations of being provided with high-quality analysis and information but it also supplies $a$ vision of the world and tools for identity construction and self-understanding to factions of dominant groups seeking to define their strategies and positions in the changing global configuration. (Starr 2004, p. 395, emphasis added)
\end{abstract}

Indeed, she has argued that The Economist seeks to develop for its readers an authoritative view of the globalized economy (Starr 2008, p. 35). This authority is developed by presenting opponents and critics of neoliberal economics as misinformed or misunderstanding the evidence; here The Economist's self-avowed focus on an analytical method is vital, rendering opposing argument as 'subjective' or 'particular' and thus to be discounted (Starr 2008, p. 49). Thus, in presenting the rule of law as a vital component to the contemporary global political economy, The Economist has contributed to, and reflected, the move to recognize it as underpinning progress and development. In the last 20 years the magazine has slowly normalized its treatment of the rule of law to the point that in the second decade of the new millennium there is little need to offer any ancillary remarks to convey the meaning; the editors just assume you know what they mean when they write the 'rule of law'; they expect readers to have become acclimatized to the rule of law. However, it was not always like that.

Because I am most interested in changes in how The Economist itself has presented the rule of law I am only going to discuss the 'op ed' pieces that precede the main news sections of the magazine, as it is here that the magazine's editorial views are set out explicitly and unapologetically. I have chosen to focus on The Economist's articulation of the rule of law for 


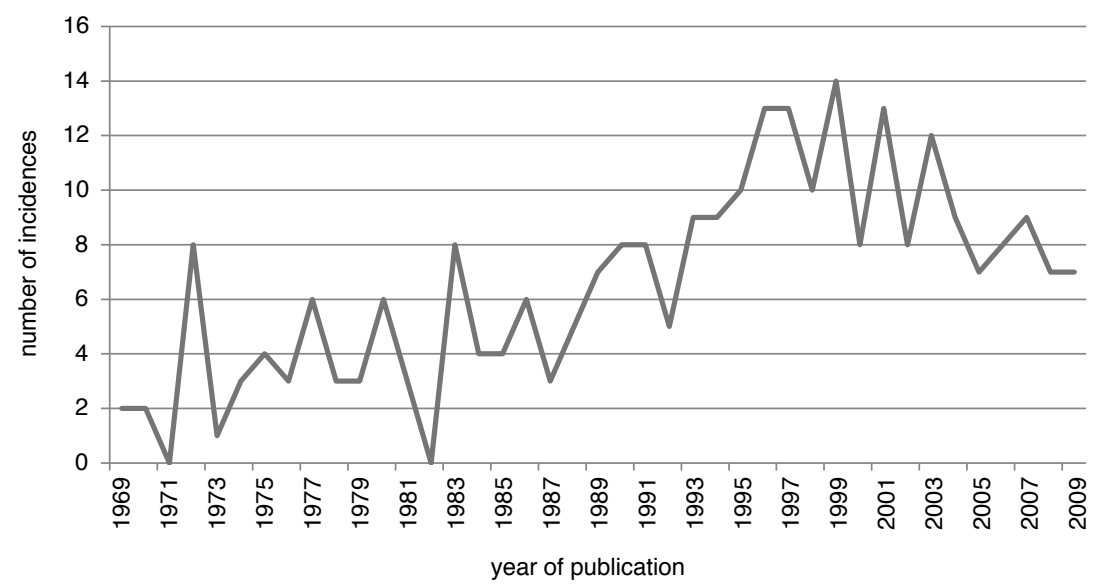

Figure I.1 The rule of law in The Economist: combined incidence of term and norm elements

20 years either side of 1989 (the end of the Cold War), not least as it seems to be the case that more generally the contemporary interest in the rule of law can be increasingly detected from the beginning of the 1990s, and I wanted to see if this was also indicated by the magazine's editorials. I will discuss both the incidence of explicit uses of the term in editorials and the uses of elements that one might regard as part of the rule of law norm (as drawn from the discussion in Chapter 2), even if these are not explicitly coded (in editorials) as the 'rule of law' (Figures I.1 and I.2). ${ }^{9}$

The first thing that is clear from the chart of combined mentions of the norm and its components is that there is a clear step change around the end of the Cold War. As far as the use of the term itself, the peak year is actually 1999 with ten editorials that year explicitly mentioning the rule of law, with the use of the elements (rather than the term) actually peaking four years earlier with seven editorials appealing to various rule of law norms (without explicitly using the term). Across the period the trend is clearly upwards with only two years containing no editorials mentioning the rule of law (or its elements); 1971 and 1982. The rule of law may not be central to the concerns of The Economist but we can nevertheless easily detect an expansion of its interest across these 40 years. Space precludes a detailed analysis of the content of 40 years of editorials (at five a week,

9 The data analysis on which the following account is based was produced by Stephen Royle (my research assistant) and to whom I extend my thanks. 


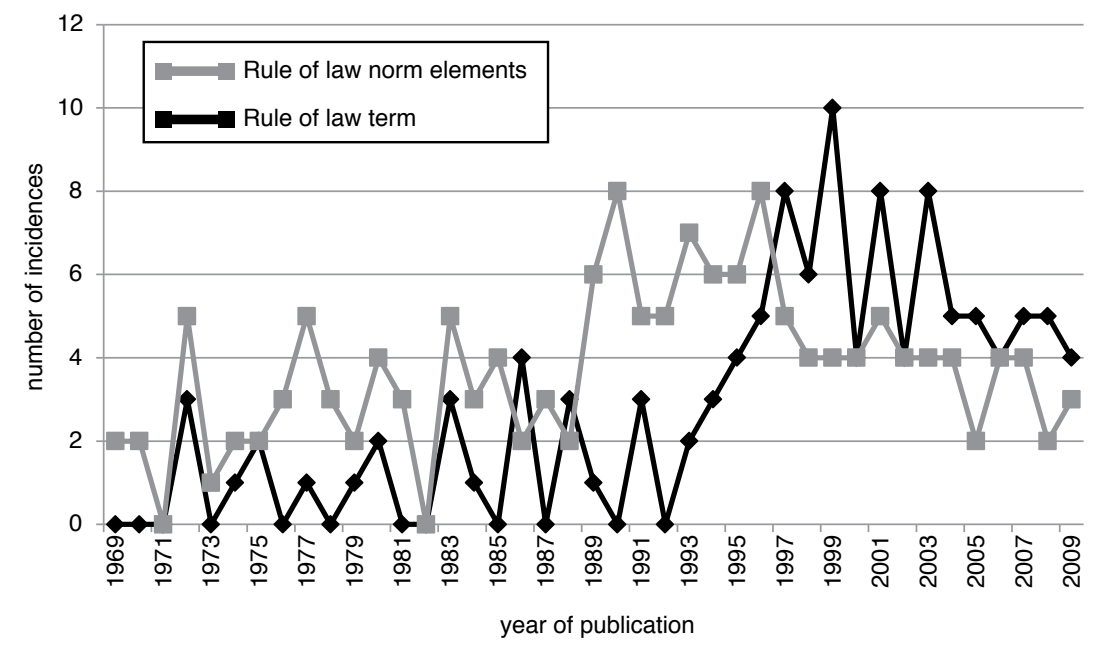

Figure I.2 The rule of law in The Economist: incidence of term and incidence of norm elements

over the period this amounts to 10,000 editorials), but it will be useful to have a look at a few snapshots of how the magazine has treated the rule of law over the years.

At the beginning of this 40-year period The Economist seemed relatively uninterested in the rule of law: in 1969 only two editorials mentioned anything related to the norm, and in both cases these were issues related to the need to enforce contract law. ${ }^{10}$ Within the period examined, 1972 sees the first mentions of the term itself, although until 1985 it never features more than twice a year and in nearly half of these intervening years is not mentioned in an editorial at all. Perhaps unsurprisingly, many of the invocations of the rule of law and/or its normative elements in the early 1970s are related to questions linked to the manner in which unions are exercising their power and influence (and occasionally this theme is revived, for instance, in a 1983 editorial by which time the Thatcher government was changing union laws in the UK quite dramatically). ${ }^{11}$ Later in the decade, the magazine's concern shifts to foreign affairs (crucially the rule of law in India and China) as well as the use of judicial review as a response to

10 The Economist, 'Half a step onward', 4 January 1969, p. 5; 'In place of government', 21 June 1969 , p. 5.

11 See, for instance, The Economist, 'Stand or deliver', 6 May 1972, pp. 13-14; 'Rule of what?', 29 July 1972, pp. 11-13; 'So who does rule?', 11 May 1974, p. 13; 'Not for spiking', 3 December 1983, pp. 14-15. 
a perceived decline in legality by the UK Labour government. The focus remains political, however, rather than making any extended link to economic development (as would develop later). ${ }^{12}$ In the early 1980s the concern for the rule of law abroad remains, but an issue that continues to be of considerable salience starts to be discussed: the relationship between terrorism and the rule of law. Here, the defence of liberalism is only possible if the rule of law is extended to its enemies as well; extra-judicial solutions merely undermine the legitimacy of the state (and therefore help the terrorists). ${ }^{13}$ Thus, importantly in these first 20 years, the notion of the rule of law as a necessary component of economic development plays almost no part in the occasional discussions of the rule of law. Until the end of the 1980s, The Economist maintains an almost exclusively political and legal perspective on the rule of law and its related normative elements when it occasionally raises the issue, even when discussing issues that would later be related to economic development such as contract law or anti-corruption regulations.

In the 1990s, however, it is possible to identify a shift both in the frequency of discussions of the rule of law and their focus. The first mention in an editorial (during the sample period) of the rule of law as part of economic development is in a discussion of the legal underpinnings (primarily property rights) required to enhance the prosperity of ethnic minorities, in 1990. ${ }^{14} \mathrm{~A}$ year later, an editorial entitled 'A prospect of growth' explicitly maintains that law and order (and by implication the rule of law) is required for economic development. ${ }^{15}$ Now a slowly growing number of mentions of the rule of law in political and legal terms is joined by editorials that link the rule of law with economic development (around the same time the World Bank was making a similar move, as will be discussed below). By 1994, editorials are starting to make the link much more explicit and the rule of law is presented as a multidimensional norm, including political, legal/procedural and economic aspects. ${ }^{16}$ Most obviously, the editorials during the 1990s increasingly set out the need for

12 See, for instance, The Economist, 'Think of a constitution', 16 August 1975, p. 12; 'Brave new India', 3 January 1976, p. 9; 'Unnecessary privilege', 23 October 1976, p. 14; 'All honourable men', 21 May 1977, pp. 12-13; 'Baby over the balcony', 16 July 1977, pp. 11-12; 'Rule by no law?', 11 February 1978, pp. 9-10; 'The best place for Bhutto', 10 June 1978, p. 15; 'China grows up', 29 September 1979, pp. 13-14.

13 See, for instance, The Economist, 'Into terrorist hands', 9 February 1980, p. 18; 'Listen, friends of Ireland', 9 May 1981, pp. 11-12; 'A bridge to Ireland', 23 May 1981, pp. 11-13; 'Law against terror', 19 February 1983, pp. 18-20; 'Is justice political?', 11 August 1984, pp. 14-15; see also 'The Irish Question', 17 April 1993, p. 16.

14 The Economist, 'Black entrepreneurs please', 7 April 1990, pp. 16-19.

15 The Economist, 'A prospect of growth', 13 July 1991, pp. 15-16.

${ }^{16}$ The Economist, 'Democracy works best', 27 July 1994, pp. 11-12. 
reform in other countries to facilitate their economic development and (re)integration into the international economic system; that is, for The Economist the rule of law has now become a key element of the global political economy. ${ }^{17}$ By the end of the decade, The Economist had started to set out a much fuller and wide-ranging account of the rule of law as a major element in economic prosperity and growth.

In the first decade of the new millennium, the focus of The Economist's attention was increasingly international with editorials focusing on individual countries that lacked the rule of law (or where it was being challenged), such as Argentina, China and Russia, while also consolidating a more economics-related approach. ${ }^{18}$ This was perhaps best exemplified by a couple of articles that while not editorials set out the position that the magazine had now adopted. In March 2008, The Economist dedicated an entire three-page 'briefing' to 'Economics and the rule of law', which intended to demonstrate that the rule of law was not only an issue for politics and/or law. ${ }^{19}$ The briefing suggests that the importance of the rule of law was prompted by the 'crumbling' of the Washington Consensus in light of its failure to produce the expected results and the search for what was missing. Citing a number of the scholars whose work I discuss later (such as Brian Tamanaha, Thomas Carothers and Michael Trebilcock), for perhaps the only time The Economist dedicates several paragraphs to the discussion of competing meanings of the rule of law to conclude that this is a discussion/debate that will never be finally resolved into a con-

17 The Economist, 'A prospect of growth', 13 July 1991, pp. 15-16; 'All or nothing', 25 September 1993, pp. 15-16; 'Patten's next stand', 2 July 1994, p. 16; 'Whose justice for the Hutus?', 30 July 1994, pp. 18-19; 'Democracy works best', 27 July 1994, pp. 11-12; 'Right to punish China', 11 February 1995, pp. 15-16; 'Can it keep the peace?', 21 October 1995, pp. 18-19; 'The republic of Oz?', 24 February 1996, p. 17; 'Changing China', 23 March 1996, p. 16; 'The quality of Korean mercy', 31 August 1996, p. 14; 'Polls to nowhere', 23 November 1996, pp. 20-2; 'After Deng', 22 February 1997, p. 15; 'Iran's new face', 2 August 1997, pp. 13-14; 'Confronting the past', 1 November 1997, p. 16; 'Clinton embraces Africa', 21 March 1998, pp. 17-18; 'Malaysia's incomplete democracy', 20 March 1999, pp. 19-20; 'Indonesia's next president', 16 October 1999, pp. 22-4.

18 The Economist, 'Ex-dictators are not immune', 28 November 1998, pp. 15-16; 'Nigeria falls apart again?', 4 March 2000, pp. 22-3; 'Peru's fight for democracy', 15 April 2000, p. 19; 'Africa's elusive dawn', 24 February 2001, pp. 17-18; 'Who will condemn China?', 24 March 2001, p. 23; 'Putin's Russia', 31 March 2001, pp. 16-18; 'Fit to run Italy?', 28 April 2001, pp. 17-18; 'Out with the old, in with the old', 9 November 2002, pp. 15-16; 'Out of Patagonia', 24 May 2003, pp. 12-13; 'Still taking on the world', 3 July 2004, pp. 11-12; 'Next steps in Colombia', 12 February 2005, p. 13; 'How to make China even richer', 25 March 2006, p. 9; 'Thou shalt not steal', 27 May 2006, p. 12; 'Unintended consequences', 15 July 2006, p. 12; 'China's next revolution', 10 March 2007, p. 11; 'Stand up for your rights', 24 March 2007, p. 12; 'A chance to change course', 20 June 2009, pp. 12-13; 'Opportunity missed', 19 September 2009, pp. 14-15; 'A good example', 24 October 2009, p. 20.

19 The Economist, 'Briefing: economics and the rule of law', 15 March 2008, pp. 95-7. 
sensual position. The briefing does, however, argue that (for economists especially) the rule of law is becoming increasingly central to discussions of growth and development. Two months later, in their 'Special report on EU enlargement' again there was a detailed discussion of the rule of law, this time focusing on the rule of law as a mechanism for reducing corruption in transition states. ${ }^{20}$ However, this extensive coverage in the main part of the magazine did not translate into any necessary expansion of the coverage of the rule of law in editorials, with 2008 down somewhat from the peak in the late 1990s.

What I have attempted to establish (albeit in a rather summary form) is that the end of the Cold War was a pivot point for the rule of law in The Economist. Prior to the end of the 1980s, its editorials were overwhelmingly focused (when occasionally mentioning the rule of law or its elements) on the political and legal aspects of the norm. However, after 1989, while this focus remained, the notion that the rule of law might be a crucial part of economic development, and that it was something that was lacking in states that sought to (re)integrate themselves with the global political economy, caused editorials to be more internationally focused as regards the benefits of the rule of law, and to also increasingly emphasize the economic benefits of acceding to the norms' strictures. Nowadays when the rule of law appears in The Economist's editorials it is seldom contextualized or defined, seen as being obviously of value and non-controversial, just common sense. This is by no means the only media or intellectual forum in which these shifts might be detected, but The Economist is a useful barometer of international elite views, while also acting to (re)produce these perspectives among those seeking to join the developed global political economy.

\section{PROFESSIONAL/SPECIALIST INVOCATIONS OF THE RULE OF LAW}

Moving into more specialized discussions, I will now explore what David Kennedy has referred to as the 'policy vernacular' of the rule of law (Kennedy 2001), as opposed to the popular rhetoric that I started with. These two sets of discussions are not unconnected, and both have contributed to the rule of law becoming the common sense of global politics. Expert ideas are only likely to be widely influential when they are seen as describing instruments rather than (political) goals (Lindvall 2009), as

20 The Economist, 'Trust me: the theory and the practice of the rule of law', in 'A special report on EU enlargement', 31 May 2008, pp. 14-15. 
may be inferred from the above discussion of the popular rhetoric, and hence one of the key developments in the rise of the rule of law norm has been its depoliticization; its (post-colonial?) move to being rendered as a technique (albeit the most fundamental) of governance. The link between the state and the rule of law has been diluted through a greater emphasis on the depoliticized function of governance as opposed to government, as I discuss below.

It is also worth noting that the understanding of the term can vary between cultures or political systems, not least because there is no differentiation in the English word 'law' between the concepts, distinguished elsewhere by different words: 'law as legislative will and Law (capitalized) as right reason' (Fletcher 1996, p. 35). Indeed, George Fletcher suggests that English commentary on law has often cultivated an ambiguity between what Germans would call Gesetz - the law as laid down, its formal rules - and Recht, which encompasses some claim to an ethical value (Fletcher 1996, p. 13). Likewise, the French distinguish loi and droit, the Dutch between wet and recht, and the Finns between laki and oikeus, to give three further (but still European) examples. ${ }^{21}$ Because of such linguistic differences the Council of Europe, as promoter of European democratic ideals, sought in its Resolution 1594 (2007) to banish translation issues from an authoritative depiction of the rule of law, noting that although the European Union, the Organization for Security and Co-operation in Europe and their member states were all committed to the rule of law there was little common understanding of the norm. They therefore sought to build on the case law of the European Court of Human Rights to stress that

the terms 'rule of law' and pre-eminence du droit are substantive legal concepts which are synonymous, and which should be considered as such in all English and French language versions of documents issued by the Assembly as well as in the member states in their official translations. ${ }^{22}$

The resolution goes on to clearly state that the rule of law cannot merely be formal law(s); there are European values focused on human rights that, even if not necessarily specifically articulated in law, nonetheless should be regarded as part of the rule of law itself. This distinction between the formal and the substantive views of the rule of law is discussed at length in Chapter 2.

Conversely, looking back a little, less than 20 years ago, Paul Cammack in a highly critical account of Capitalism and Democracy in the Third

21 I am grateful to Jan Klabbers for this point and examples.

22 See Council of Europe, Resolution 1594 (2007), available at http://assembly.coe.int/ASP/ Doc/XrefViewHTML.asp?FileID=17613\&Language=EN (accessed 17 May 2013). 
World (Cammack 1997) made no mention of the rule of law, hardly referring to law or legal structures at all; although occasionally mentioning the protection of property rights, he never contextualizes this in a wider analysis of the role of law in capitalism or democratization. Then this would have hardly been noteworthy, but now would seem to be missing a key element of the debates about which he was concerned. It is the debates that have changed, however. Similarly, in Capitalism vs. Capitalism, Michel Albert's much cited discussion of the clash between the Anglo-American and German/Japanese models of capitalism (Albert 1993), the role of lawyers and litigation is presented as a cost on business, but the rule of law (explicitly) or the legal structures required by capitalist market economies are not discussed. Again, Samuel Huntington's wellknown (and often cited) discussion of democratization, The Third Wave (Huntington 1991), occasionally elliptically mentions legal practices and issues, but has no detailed account of any links between democracy and the rule of law (although he mentions in passing that the Helsinki Final Act in 1989 linked them) (Huntington 1991, p. 89). In a long list of variables underpinning democracy, near the bottom (23rd in a list of 27) he includes 'traditions of respect for law and individual rights' (Huntington 1991, p. 38), which might be a proxy for the rule of law. However, while dispensing all manner of advice to would-be democratizers of the 'third wave', Huntington remains ambivalent and largely silent on the role of the (rule of) law; an omission that would hardly pass unremarked today but which in his more recent work he has not repeated. Thus it is perhaps unsurprising that in the mid 1980s Mark Kelman found only 20 books in the Stanford Law Library that focused on the rule of law and half of those were appealing for an international rule of law as a way to promote peaceful coexistence (Kelman 1987, p. 292). A search only on my own bookshelves would now produce at least three times that many!

This is not to say, however, that debates about the rule of law were necessarily absent from discussions of international politics before the end of the Cold War. In the late 1950s Abbé Jean Boulier criticized the International Commission of Jurists' (ICJ) position (and work) on the rule of law in an argument that would be familiar to many on the left today. He argued that the ICJ was hopelessly compromised by its depiction of the capitalist rule of law, which included no space for a more pluralist definition that would allow non-capitalist states to enjoy the benefit of being part of a wider society that valued the rule of law (Boulier 1958). In his view the ICJ, despite protestations of neutrality, was prosecuting a liberal project, and thus continuing the Cold War by other means. The ICJ's position would also not be unfamiliar today (and indeed is often referred to by those claiming a historical trajectory for the norm); for the 
ICJ, the rule of law embraced a 'broader conception of justice than the mere application of legal rules whatever they happen to be in any particular state at any given time' (ICJ 1966, p. 2). Across a number of meetings, the ICJ's members sought to elaborate their view of the rule of law, and defend their conception against critics like Boulier, presenting the rule of law as 'dynamic' by recognizing (at conventions held in Africa, Asia and South America) how the rule of law was actually adopted and recognized in a wide variety of states (with the exception of totalitarian states) (ICJ 1965, pp. 14-17). ${ }^{23}$ While of limited general political visibility, the work of the ICJ seems likely to have contributed to the early elaborations of the rule of law norm that pre-dated its more recent ubiquity.

At least until the 1960s these sorts of discussions were highly specialized and were seldom conducted outside closed events and remained confined to limited circulation publications (Marsh 1961). In the final quarter of the twentieth century and into the new millennium this relative obscurity has been transformed by the rise of the rule of law as a key and explicit component in (global) political order. As Paul Kahn has suggested, by the turn of the millennium, the

West had taken a decisive turn towards the rule of law as the single source of political order. A modern constitution imagines no political situation or action to which the law does not apply: it can imagine nothing that cannot be evaluated as a matter of law. (Kahn 2011, p. 54)

In this view political rhetoric now reaches most often towards the law for responses; invocations of the rule of law allow actions and situations to be swiftly judged and clearly communicated.

David Trubek argues that the rule of law is an increasingly deployed rhetoric because it represents the common ground between the contemporary political 'projects' of democracy (democratization) and of markets (or neoliberalization). In both cases the rule of law represents a set of institutions that can be depoliticized and presented as a technical response to shortcomings of society without the ideological baggage that would come with more explicit demands for democracy and liberalization (Trubek 2006, pp. 84-5). Thus, as David Kennedy puts it:

There is something mesmerizing about the idea that a formal rule of law could somehow substitute for struggle over [political and economic] issues and choices - or could replace contestable arguments about the consequences

23 An account of the competing colloquia (one in Chicago, one in Warsaw) in the late 1950s that sought to find a consensual definition (and substantive content) for the rule of law can be found in Marsh (1961, pp. 230-40). 
of different distributions with the apparent neutrality of legal best practice. (Kennedy 2006, p. 144)

The rhetoric of the rule of law may be popular just as much for what it obscures as for what it says about any particular political evaluation. For instance, the Princeton Project's self-avowedly bipartisan report, Forging a World of Liberty Under Law, suggested that to enhance support across the political spectrum, one of the new (and narrower) foci of US foreign policy should be 'strengthening the rule of law, personal freedoms and democratic governance' (Princeton Project 2006, p. 59). The report emphasizes in a number of places that the rule of law is a crucial part of the structure of liberal democracy that the USA should seek to promote (Princeton Project 2006, pp. 29, 59); however, it does little to fix the normative meaning of the term in use other than to repeatedly link it to the protection of liberty and the provision of 'accountable government, basic civil rights and civil liberties' (Princeton Project 2006, p. 39), leaving the rule of law as a surprisingly underspecified aspiration for interventions, which seemingly requires no detailed justification.

As this indicates, the rule of law is often bundled together with other values of the (so-called) 'international community' when they are expressed by its (self-proclaimed) leaders: democracy, human rights and the contribution of markets to development (Barnett and Duvall 2005, p. 6). However, not all commentators agree that these values are so closely linked. Fareed Zakaria (at the time the editor of Newsweek International) argued at length that while the rule of law is certainly a crucial liberal value, not least of all in its role of protecting liberty, it is less clear that it is necessarily co-terminus with democracy (Zakaria 2003). Here the rule of law can protect against the excesses of democracy and its dangers. In another well-known intervention, Hernando de Soto promotes the rule of law as a method for freeing the poor from the constraints that stop them capitalizing on their creativity and entrepreneurship (which I discuss in Chapter 5); this is a story that policy makers frequently welcome. In his analysis the rule of law presents a way of fostering localized development without having to go against the strictures of the multilateral aid agencies and institutions (de Soto 2000). Helpfully, de Soto's prescriptions are fully compatible with the recommendations of the World Bank and others.

The contemporary strength of the norm of the rule of law articulated and promoted by key international agencies also encourages states to adopt this language or terminology (even if their actions may fall short); to celebrate being a state that does not accept the rule of law no longer seems to make sense. As Shirley Scott and Olivia Ambler observe: 
States often demonstrate their acceptance of the ideology of international law by referring in their rhetoric to the 'rule of law'... [but this] ideology of international law is integral to the international distribution of power, and hence the rhetorical emphasis that the US has for many decades placed on the importance of the rule of law has served not only to strengthen international law but [also] to reinforce a source of legitimacy on which the US has frequently drawn. (Scott and Ambler 2007, pp. 72, 74)

The rhetoric may serve different states' governments differently, with some using it to demonstrate an interest and willingness to be seen as part of the 'international community' while more powerful states (most obviously the USA) use the rule of law as a method to legitimate their position.

Additionally, it is possible that the expansion of the rhetoric of the rule of law is a response to perceived illegality (and its costs) in the now globalized political economy. If 'deviant globalization' is as widespread as some commentators believe (see, for instance, Gilman et al. 2011) and criminal activities are integral to the flows and structures of the global political economy (Friman 2009), then one response would be for governments to ratchet up the calls for the rule of law globally. This would especially be the case as black markets and illegal activity, centred on morally suspect services and products (drugs and the sex trade), are frequently an adjunct to 'legitimate' globalization. Of course, in one sense it is the rule of law that produces the criminal activity by establishing the distinction legal/illegal, but its rhetorical use also leaves aside political discussions about the value or otherwise of prohibition or the question of what encourages such activity, to focus on issues of security and stability. Here, the rhetoric of the (lack of) rule of law becomes a way of summarizing problems in the international system that stem from the ability of criminal actors and organizations to enjoy sanctuary from which they can operate across the global system.

The use of the rhetoric of the rule of law to identify the 'lawless' has been an abiding theme of US political development: repeatedly 'lawless others' have been subjected to domination and/or violence in the service of the greater civilizing project of manifest destiny. Natsu Taylor Saito argues that recent instances of US self-exemption from the rule of law are merely the contemporary (re)iterations of a one-sided view of the rule of law (Saito 2010). The rule of law for others but not us, as it were! Conversely, in an extended critique of Jack Goldsmith and Eric Posner's criticisms of the efficacy of international law, Michael Scharf has argued that when one actually examines the opinions/advice of the US State Department of Legal Advisors (and the impact of this advice on US foreign policy) one sees a much higher level of recognition of the legitimacy of international law than would be expected by critics (Scharf 2009). Thus, following Louis Henkin's famous assertion (Henkin 1979) it does seem that most of 
the time most states (including the USA) do abide by their international legal obligations, allowing them to argue that the rule of law does obtain in the international system. The culture of the acceptance of the rule of law is constantly being promulgated and supported in the global political system, making explicit rejection difficult (in diplomatic terms at least). One of the main but by no means only organization that works hard to promote the rule of law is the World Bank.

\section{THE RULE OF LAW AT THE WORLD BANK}

The World Bank is one of the most important (and influential) producers of knowledge about development in the world today. It is not just the extent of its lending that makes the Bank influential; as Catherine Weaver suggests, 'what it says about development shapes other multilateral, bilateral, and national governmental strategies and defines the conventional wisdom on global development' (Weaver 2008, p. 10, second emphasis added). For Weaver, the 'power the World Bank enjoys in shaping global ideas about development theory and practice is arguably un-replicated by any other development agency, think-tank or university' (Weaver 2008, p. 73). Bank President James Wolfensohn made research a central element in the Bank's activities in the mid 1990s, and certainly since then the production and dissemination of authoritative knowledge has been significant (van Waeyenberge and Fine 2011). Therefore, the Bank's 'discovery' of rule of law reform marked an important shift towards the rule of law becoming a common sense of global politics. Linked to the move to consider 'governance' as within the Bank's remit, the rule of law was depicted as a depoliticized technology. The timing of this move is hardly inconsequential: at the end of the Cold War and the collapse of the communist bloc, the World Bank in the early 1990s was seeking a different set of justifications for its policy prescriptions and aid interventions; governance and the rule of law fitted this need rather well. ${ }^{24}$

In the late 1980s (and into the 1990s) Ibrahim Shihata (then the Bank's General Counsel) made a strong case that to further its developmental aims, the Bank needed to attend to the manner in which states were governed to ensure that the aid provided was used effectively and efficiently (Shihata 1991a). Responding to increasing internal pressure for governance to be taken seriously (Weaver 2010, p. 58), Shihata carefully

24 Guilhot (2005, pp. 188-221) offers an extended history of the manner in which the World Bank's involvement and interest in human rights evolved over its history; see also Weaver (2008). 
reconsidered the Bank's statutes and mandated mission, allowing him to introduce 'good governance' as an area that required attention, and which had previously been undersupported with some negative impact on the efficacy of Bank programmes in recipient countries. Shihata's move was successful due to the clear failure of developmental policies (particularly) in Africa where state structures were unable to support (or facilitate) the sorts of policies the Bank favoured (Guilhot 2005, p. 213; Krever 2011, pp. 299-301). Alongside increasing engagement with non-governmental organizations focused on human rights, these practical failures opened up a space for an approach that stressed the need for good governance for development policies to be successfully initiated and sustained.

However, the depoliticized character of Shihata's discussion of governance and the rule of law also reflected the ideological terrain of research within the Bank that remained dominated by (neo)classical economists who were resistant to anything that resembled political theory. This prompted Shihata to focus on the law as an enabler of market-based development (Weaver 2008, p. 107); the rule of law was conceived as a limitation on the ability of the state to 'interfere' in the private sector, rather than a more positive (and political) perception of the rule of law as underpinning social development (in terms I will introduce later, Shihata's is a thinner reading of the rule of law). The difficulty of articulating this position is that such a depiction of the rule of law, intended to establish its non-political character (and thus its universality), is historically specific; it is how the (rule of) law has been conceived of in liberal capitalist societies (Krever 2011, pp. 317-18; Tshuma 1999, p. 85). Laws that were not 'market friendly', or more specifically that did (or do) not support standard capitalist economic relations, are not regarded as 'good' laws nor central to the rule of law.

Shihata's rhetoric on the role of law in development (which would quite quickly become orthodoxy at the Bank) is essentially circular: a good law (or legal system) is one that promotes development (as defined by the Bank), while the success of the developmental process (as supported by the Bank) is demonstrated by the existence of a rule of law that fosters and supports development (Pahija 2011, p. 198). Once the Bank was able to (re)focus on 'good' governance as a key determinant of developmental success, and given that (almost) any form of governance will involve the rule of law, the justification for (potentially) wide-ranging intervention in the politico-legislative system of recipient states was in place, provided it was supporting economic development. As Sundhya Pahija puts it:

The absence of a positivistic system of law justifies intervention to further development as a process, but development as an end-point justifies the privileged 
place of positive law in the first place. And if a society demonstrates reluctance to embrace such a legal system, then that reluctance become further justification for the necessity for intervention. (Pahija 2011, pp. 198-9, emphasis added)

Thus, by shifting the Bank's concerns towards good governance, Shihata (and those within the Bank promoting this approach) achieved a significant move towards more strident intervention in recipient states' political systems. However, for these interventions to continue as part of the Bank's activities, the 'myth' that these were only intended to address economic and/or technical problems had to be maintained (Weaver 2010, p. 62). This required strong (ideological) maintenance of the 'technical' presentation of the rule of law.

Once the World Bank articulated (repeatedly) the relationship between the rule of law and economic development, beginning in the late 1980s/ early 1990s, then even organizations that broadly kept clear of 'political' concerns could involve themselves in the promotion of the rule of law 'as developmental technology' by referring to the Bank's position (Pahija 2011, p. 185), and, as noted above, around this time The Economist also shifted its treatment of the rule of law (quite possibly influenced by materials from the Bank). In Nicholas Stern's history of the first 50 years of the Bank's intellectual role in global politics, it is notable that the notion of the rule of law is largely absent, and in data from 1991 on the staff profile of the bank, those with legal training are a vanishingly small proportion of the staff employed at that time (Stern and Ferreira 1997, p. 586, passim). However, this was changing almost at the same time that Stern was compiling this history. As one commentator puts it, the Bank's lack of interest in the law was replaced at this time by the view that the rule of law is 'a magic wand that promises to resolve virtually every conceivable economic and social problem' (Faundez 2005, p. 568), although this may have been sustained by the lack of lawyers on the staff who might have had a more nuanced view of the possibilities of law.

Michael Goldman has concluded that 'Bank knowledge is a tactical technology whose power should not be underestimated, whatever one's interpretation of its truth value' (Goldman 2005, p. 135). He quotes a Bank-contracted environmental technician: 'You and I may say that our World Development Reports are BS [bullshit]. But I go to Sri Lanka and officials there quote from the latest report word for word. That's music to our ears' (Goldman 2005, p. 145). Therefore, it will be useful to briefly examine a couple of crucial World Development Reports (WDRs) and to see how the rule of law appears on the website of the World Bank, these being two important aspects of the organization's public face.

The WDRs are a key carrier of the World Bank's position(s) and are an 
important conduit through which the view of the rule of law established by Shihata was disseminated to the (global) policy community. One is particularly important in this regard: the 1998 WDR - From Plan to Market. Space precludes an extensive treatment of the manner in which each successive WDR has accepted and built on the conclusions of From Plan to Market but, for instance, in following year's report, The State in a Changing World, the Bank allows that states have generally expanded their share of gross domestic product (GDP) and seeks to ensure that they are doing what the Bank's analysts believe is of value. The first item on the list entitled 'First job of states: getting the fundamentals right' is: 'Establishing a foundation of law' (World Bank 1997, p. 4). This focus on law is limited throughout the report to a concern for the sanctity of property rights, the predictability of market rules and the need to limit corruption (none of which might be objectionable, but as the subsequent chapters will show is a relatively limited view of the rule of law).

This limited focus may indicate that the writers of the 1997 report expected their readers to have read and digested the previous year's report, which contained an entire chapter on the rule of law. Largely focusing on the post-communist transitional states (but also drawing more general conclusions), From Plan to Market acknowledges that many countries are conducting forms of legal reform but emphasizes that the effects have been uneven (World Bank 1996, p. 13). Interestingly, before reaching the chapter on the rule of law the reader is introduced to the importance of property rights (World Bank 1996, pp. 48-9), here emphasizing the prioritization of legal structures that the following year's WDR would also exhibit, and stressing the establishment of assigned property rights to the strategy of privatization in transition economies. In the next major section of the report on the consolidation of change(s) in societies that are in transit between their communist past and their new future, which will be more fully engaged with the global capitalist economy, the 'legal institutions of the rule of law' are the first element discussed, at some length.

Chapter 5 of From Plan to Market focuses on 'developing the rule of law' and stresses that this can only be achieved by both the top-down legislative development of 'good' laws, alongside the 'bottom-up demand' for the rule of law (World Bank 1996, p. 87). However, as the chapter progresses to specifics, the forms of law that are focused on move from those that might (plausibly) be meeting a widespread demand (property) to those for which the demand is likely to be coming from a focused business community (both domestic and foreign); company and investment law (World Bank 1996, pp. 90-1) and competition law (World Bank 1996, p. 92). The latter is summarized as the dismantling of monopolies (often specified as state-owned) to allow new competitive market entrants. The 
rest of the chapter then moves to focus (again) on issues of some wider salience such as the reduction of corruption and the defeat of organized crime (World Bank 1996, pp. 95-6). These are brought together as ways of increasing the level of trust in the state and enhancing its credibility to the 'business community', and of delivering constraints on the (abuse) of state power. Most crucially, while issues of democratization's link to the rule of law are included, the thrust of the discussion is about the ability of the rule of law to both help foster development and for development to enhance/expand the 'demand' for the rule of law itself (World Bank 1996, pp. 97, 144). In the following WDRs the rule of law is more taken for granted as underlying condition development rather than something that again has to be set out. In Building Institutions for Markets (World Bank 2002), for instance, there are a number of aspects of the rule of law discussed (such as reform of the judiciary and the regulations of markets) but the overall need for the rule of law is taken as a given throughout the volume.

The World Bank also seeks to influence states' governments (and policy makers) through other means. I look at the programmes supporting rule of law development in Chapters 4 and 5, but it is worth also noting that the Bank's website represents a major depository of materials intended to support the Bank's reading of the rule of law. Two clicks away from the home page, under 'topics': 'Law, Justice and Development', the following statement appears at the top of the main page: 'The rule of law is a principle of fundamental importance to the World Bank. It lies at the heart of what the Bank is, what it does, and what it aspires to accomplish. ${ }^{25}$ There are also a number of resources on the various elements of the website, with a large number of reports under the 'projects and operations' segment where the rule of law has its own section. Although far too numerous to consider here, the extent of the World Bank's operations can be gauged from the over 800 project reports that are available under 'rule of law'. Most interestingly and following a decade of the Comprehensive Development Framework (CDF), the rule of law is now so well embedded that it is much less stridently pushed as now 'good governance' (and thereby the rule of law) has been mainstreamed. The move from an earlier structural adjustment, through a period of governance (during the 1990s) to the CDF in the new millennium (Santos 2006, pp. 267-8) has therefore involved the move from the rule of law as technology requiring separate justification and stipulation to the position now (as common sense) where

\footnotetext{
${ }^{25}$ See http://web.worldbank.org/WBSITE/EXTERNAL/TOPICS/EXTLAWJUSTICE/0, menuPK:445640 pagePK:149018 piPK:149093 theSitePK:445634,00.html (accessed 29 April 2013).
} 
it is embedded in the World Bank's more comprehensive approach to development and requires no separate justification.

Because the rule of law is (still) understood by the Bank as a depoliticized developmental technology, albeit embedded within a more general approach to socio-economic development, any requirement for knowledge of the local legal systems of recipient countries is downplayed and undervalued. Indeed, Weaver quotes a staff member lamenting that as regards governance, the Bank lacked a 'real working theory of the state' (Weaver 2008, p. 93), making it clearly difficult to engage with discussions about the particular (and local) political developments behind the 'mechanisms' of governance. Thus, a common criticism of World Bank and other rule of law programmes has been the ignorance of local circumstances and their impact on the introduction (or expansion) of the rule of law (Tamanaha 2011). Although by no means limited to the World Bank, Julio Faundez's more general criticism certainly seems to apply to Bank programmes:

The blend of legal formalism and instrumentalism is a convenient methodological shortcut as it enables [legal support] practitioners to offer legal advice without having to go through the tedious, difficult and often unrewarding task of understanding the societies they purport to help. (Faundez 2005, p. 574)

I will return to the issue of local culture and the rule of law in Chapters 4 and 5 but here merely note that this is hardly a surprising outcome from the presentation and discussion of the rule of law as a (universal) depoliticized technology.

Although the World Bank's adoption of the rule of law as an anchoring concept is important, the Bank in one sense was late to the field, following in the footsteps of the law and development movement of the 1960s and 1970s. For some commentators this suggests that the Bank's influence is therefore overstated (Hammergren 2010). Moreover, within the Bank the understanding of the rule of law is hardly monolithic; rather like a duck on a calm pond, while externally it presents a commitment to the rule of law, beneath the surface different parts of the Bank (such as the Legal Department or the Public Sector Unit) seem to deploy varying understandings of its character (and crucial elements) and be in continued discussion about its role (Santos 2006). Nevertheless, what is notable is that while the law and development movement struggled to expand its reasoning beyond the specialist context in which it worked, the Bank seems to have contributed to a much wider recognition of the rule of law's role in (global) society, even if this has not produced anything approaching consensus on its 'necessary' character.

Finally, while there is a considerable literature that discusses and analyses the rule of law, it is far from clear that there is much substantive 
connection between the Bank's and other specialist depictions and the invocation of the rule of law in the more popular discussions that I discussed above. They all may share the term, but the understanding of what the rule of law entails is often different, and in the popular rhetoric vague and underdeveloped; often meaning little more than law is important to governance (Brooks 2003, p. 2283). However, the recitation of the shared terminology has allowed it to become widely deployed (if less well understood) precisely because different groups all seem (at least) to be discussing the same the thing. This is not to say that these discourses are completely unconnected but rather that while the term flows pretty freely between various groups its meaning is less well travelled, leading to quite wide variances in how the rule of law is understood, even as it is widely appealed to.

This chapter has been intended to illustrate Lord Bingham's claim that the rule of law is 'constantly on people's lips' in the political classes and more widely, but this is not necessarily to claim that the rule of law is uncontroversial or a settled concept. Many states may claim they are subject to the rule of law but often these claims can be peeled away to reveal practices that hardly accord with all the elements that might plausibly be drawn from the definitional debates that I will set out in Chapter 2. Nevertheless, what I suggest we do see is an extensive and widespread invocation of the rule of law as a political norm, without any necessary consensus on what the substantive content of this norm would be beyond some pretty basic procedural practices. In Chapter 3 I will examine some arguments about the norm's carriers and its agents of (re)production as well as the timing of the 'legalization' of global politics, but what I have sought to establish here is that the rule of law is much discussed, even if its articulation is often accompanied by little detailed specification of what it might actually entail. 
Christopher May - 9781781008959 Downloaded from PubFactory at 04/25/2023 11:41:24PM via free access 